\title{
AXIOLOGICAL ORIENTATION AS A FORMATION FACTOR OF GENDER TOLERANCE IN STUDENT-AGE POPULATION
}

\author{
LIUBOMYRA PILETSKA, VITALIIA DOBROVOLSKA
}

\begin{abstract}
In the article, we carried out a theoretical analysis of gender tolerance concept and determined external and internal factors of its formation. There were distinguished the levels of our research concept: high, average and low; listed the main principles of gender tolerance, proposed the structure that includes four components: cognitive, emotional, behavioral, axiological; defined the characteristic features that merge in tolerant person. Axiological orientations are inner factors of gender tolerance formation that include instructions, beliefs, needs, objectives, motives, ideals, affirmations and values. The listed components have been grouped into three blocks: cognitive, motivational, operational, and distinguished the indicators of gender tolerance. We have emphasized the importance of study of psychological gender of personality, values, affirmations and beliefs, degree of acceptance of gender stereotypes within the range of research problem that will advance the level of gender culture.
\end{abstract}

Keywords: gender tolerance, axiological orientations, instructions, beliefs, needs, objectives, motives, ideals, affirmations, values, psychological gender, gender stereotypes.

\section{INTRODUCTION}

The problem of gender tolerance formation has become a sensitive issue over the last decades. Ukraine has gained independence and formation of free and democratic state provides for equity of citizens irrespective of sex, age or religion. As a counter to it, we have to confront quite frequently the phenomenon of intolerance in modern society and in different spheres of life and interpersonal relations. The crusted gender stereotypes, imposition of "correct" views on behavior, appearance, sexual orientation, of the representatives of certain gender are constantly influencing our consciousness depriving of possibility to form own view on the present range of problems. This is the reason why gender education of school and university students, cultivation of gender equity ideas, provision of successful gender socialization and formation of gender identity are one of the most important tasks of modern education. The mentioned processes are occurring in parallel to the formation of personal axiological system that serves as the original regulator of behavior and determine its purpose; determine their attitude to these or those phenomena and so on.

S. Saharso write that "compared to France, concerns about secularity and state-neutrality, national identity and equality, all find resonance in the Belgian context, but are articulated in a more ambiguous and less 'principled' way. This partly explains the paradoxical situation in which, despite a widespread 
resistance to a general law banning the wearing of religious symbols in public schools, in practice, headscarf prohibitions are on the rise throughout various regions of the country. Although issues of gender equality and cultural diversity often cut and flow across debates and policies in European nation states, the Belgian hijab question provides a unique case, because of various lines of fracture and processes of increasing diversification that characterize Belgian society" [8]. Gender stereotypes are especially found in multinational states. This problem is also relevant for countries in Africa and Asia. In this context, the value orientations of people are significant. Thereby, we shall consider the axiological orientations as one of the most important aspects of gender tolerance formation.

The aim of the article is to substantiate theoretically the concept of gender tolerance and determine the influence of axiological orientations on its formation.

Different aspects of gender tolerance problem were studied in the scientific context: psychologicalpedagogic aspect of the process of personality gender socialization (S. Bem, O. Budnyk, P. Hornostai, I. Klotsyna, T. Tytarenko and others), research in the area of education (O. Bodnarchuk, T. Hovorun, L. Karamushka, O. Kikinedzhi, S. Maksymenko, O. Nezhynska and others); development of gender tolerance in children and young people (H. Bardier, L. Shustova); gender tolerance as an integral characteristic of personality $(\mathrm{H}$. Bardier, H. Verzhybok, M. Matskovskyi, Ye. Chernyshova, J.Schnittker, L. Shustova and others). The problem of axiological orientations is considered in the research works of M. Aleksieieva, B. Ananieva, H. Ball, M. Boryshevskyi, Ye. Holovakha, O. Zdravomyslov, H. Kostiuk, O. Leontiev, S. Maksymenko, V. Miasyshchev, S. Rubinshtein, V. Yadov, A. Maslow, K. Rogers, V. Frankl and others. Diversity of approaches to the research of personal tolerance, in general, and gender tolerance, in particular, stipulates the need of the analysis aimed at the determination of gender tolerance conceptual essence in university students.

\section{ANALYSIS AND DiscusSiON}

Majority of scientists consider gender tolerance as unbiased attitude to the representatives of other gender and persons that demonstrate the behavior different from the standard inherent to their gender, inadmissibility of gender based attribution of defects to a person, following gender stereotypes, display of discrimination based on both biological and socio-cultural gender features. The concept of gender tolerance is the product of western culture as the concept of tolerance in general. It is connected historically with the process of human emancipation initiated by bourgeois revolutions and formation of new era - era of human rights and revision of power relations in the society: from subject-object they become subject-subject relationships. This is an individual position that reveals affirmations, values and motives of a person, and on their basis is made a conscious choice that is determining in building behavior strategy [7, p. 142-143].

"Female characters are rated as less dangerous to others; this partially accounts for the effect of gender on self-perceptions of social tolerance. This effect does not vary significantly across the different types of problems portrayed. Furthermore, women and men do not differ in their perceived willingness to interact with or ratings of dangerousness of characters portrayed with psychological problems. Finally, gender-symmetry (i.e., when the respondent and the character are of the same gender) influences self-perceptions of social tolerance" (J. Schnittker) [5].

The mentioned interpretation enables us to see correlation between the concepts of gender tolerance and axiological orientations, as the latter includes instructions, beliefs, needs, objectives, motives, ideals, affirmations and values. We shall come back to the concept of axiological orientations somewhat later and distinguish the principles of gender tolerance: collaboration and productive interaction between the representatives of different genders; readiness to accept the opinion of opposite gender partner or partner that has different views on gender behavior; respect to human being irrespectively of biological or socio-cultural gender features, gender self-identification; acceptance of other person the way they are; recognition of individual identity; tolerance to atypical gender behavior; refusal from dominance, harm and violence (moral and physical). Compliance with the listed principles will 
contribute to conflict-free interaction between genders and formation of gender tolerance and own opinion on the specified range of problems.

According to the research by O. Voloshyna on the levels of formed tolerance in general, we have distinguished the levels of formed gender tolerance: high, average and low. High level provides for presence of knowledge on gender tolerance, readiness to carry out educational activity in the field, participate in the dialogue and build effective interaction with the representatives of opposite sex or persons with different views on gender related behavior or appearance. High level is characterized by active position and capacity to lead the way in the situations of gender problems discussion, readiness to create the respective situations. Average level provides for presence of knowledge on gender tolerance, however, gaining such knowledge is not initiated by the individual themselves; desire of deeper comprehension or discussion of the problem with other persons is not observed. It would be appropriate to characterize such level as neutral, as the manifestations of sexism or gender based discriminations are not observed, but they are not supported by deep awareness and desire to share knowledge with others having as a purpose reduction of such phenomena manifestations in the society. Low level of formed gender tolerance means absence of knowledge on the mentioned concept or presence of superficial knowledge that forms erroneous idea on gender tolerance, passive position when discussion takes place, unavailability for interaction, and misunderstanding of value of another person.

Based on afore-cited, it is important to distinguish the features that are combined in a tolerant person, namely:

- empathy (capacity to show compassion and understanding of another person);

- lability (flexibility in views, capacity of action with consideration of the situation);

- liberality (non-critical perception of other person's beliefs that contradict ours, understanding of variety of thoughts and models of behavior);

- humanity (refusal from any form of violence, recognition of human being value irrespectively of sexual belonging);

- self-regulation (control of own emotions, behavior and so on).

Next, there originates the need to form gender tolerance structure. In our opinion, gender tolerance includes the following components:

- cognitive - presence of knowledge on gender tolerance, comprehension of its principles, acquisition of the concepts of gender identity, socialization, gender stereotypes, recognition of equity of all people;

- emotional - empathy, discretion, benevolence and emotional stability;

- behavioral - behavior that does not violate the rights of other person, refusal from violence (physical or moral), sexism and discrimination of others based on gender features;

- axiological - recognition of other person as a value irrespectively of their sexual orientation or inherent form of gender identity (for example, queer identity that includes transgender, homosexual and lesbian identity).

After discussion of the principles, levels and structure of gender tolerance, it is expedient to consider the factors that influence its formation. It is clear that there exist a big number of such factors. For example, general social situation (quality of people's life determines their tolerance, capacity to understand others, benevolence; social tension determines aggression and intolerance), quality of interpersonal relations, satisfaction with work conditions, family relations, conditions of socialization, degree of gender stereotypes influence [1]. We can define such factors as external, however, we should not forget about internal factors, namely: individual-psychological peculiarities, formed beliefs, interests, values, objectives and motives or axiological orientations of an individual.

In our research, we make an accent precisely on internal factors of gender tolerance formation, on axiological values to be more exact. There are many approaches to the study of the problem of axiological orientations, and that is why the unanimous definition of this concept does not exist. In Soviet psychology, the system of axiological orientations was determined through the concept of personality orientation (S. Rubinstein, H. Andrieieva and others) [4]. Axiological relations are formed in 
the process of social interaction, and then are transformed into social affirmations, and after some transformations - into axiological orientations (N. Frolova) [2]; result of reflection of the existing social axiological relations in person's mind (R. Shulha) [6]. Many scientists deem the axiological orientations as the most important elements of personality's internal structure that are consolidated by life experience of an individual (A. Furman) [3].

In the basis of our research lies the psychological structure of axiological orientations developed by P. Ihnatenko, where are distinguished the following components: needs, instructions, interests, motives, objectives, ideals, consciousness, beliefs, choice, values. Based on the study of mentioned components, we have proposed to group them into three blocks, namely: cognitive, operational and motivational, that will be useful in correct statement of gender tolerance indicators. Cognitive block includes personality's values, ideals and affirmations. This is a system of knowledge on gender tolerance, readiness to perceive information within the range of mentioned problem, awareness of own psychological gender (according to S. Bem - femininity, masculinity and androgyny). Within this block, we divide values into terminal and instrumental (M. Rokych). Characteristic feature of formed gender tolerance will be the presence of such terminal values as will, happiness of other people and life wisdom, and respectively, instrumental: good breeding, diligence, independence, tolerance, liberality and tactfulness. Operational block includes instructions and beliefs and provides for personality's readiness to make a conscious choice of behavioral pattern that is not manifested by sexism and discrimination. Motivational component includes needs, objectives and motives and is characterized by the desire of conscious behavior regulation that is not based on acquired gender stereotypes. Therefore, in this field of research grows the topicality of both theoretical and applied research. The study of psychological gender of personality, values, affirmations and beliefs, degree of gender stereotypes will enable further study of practical influence of the axiological values on gender tolerance formation.

\section{CONCLUSIONS}

Thus, the analysis of the problem ascertains that gender tolerance is an unbiased attitude to the representatives of opposite sex and persons with inherent behavior that is not characteristic for their sex, inadmissibility of gender based attribution of defects to a person, following gender stereotypes, display of discrimination based on both biological and socio-cultural gender features. Formation of gender tolerance is influenced by many factors, in particular: general social situation, quality of interpersonal relations, satisfaction with work conditions, family relations, degree of gender stereotypes influence, individual psychological peculiarities, formed beliefs, interests, values, objectives and motives or axiological orientations of personality. Axiological orientations represent a steady structure that determines personality orientation and includes instructions, beliefs, needs, objectives, motives, ideals, affirmations and values. There were singled out three blocks (cognitive, operational, motivational) that include the listed components; indicators of gender tolerance; three levels of formed gender tolerance (high, average and low); principles of gender tolerance, compliance with which will promote a conflict-free interaction, formation of own position on the given range of problems and gender tolerance, in particular.

\section{REFERENCES}

[1] Budnyk O. Ethnic socialization of personality: space of family educational traditions of the XXI-th century. In: Zimny J., Król R. (Eds.) Wychowanie u Początku XXI wieku. Stalowa Wola - Kijów Ružomberok, 2012, 235-245.

[2] Frolova N. Transformation of axiological orientations. Synopsis of thesis for the scientific degree of Candidate of Psychological Sciences: 19.00.01. Kyiv, 1998. (in Ukrainian) 
[3] Furman A. Axiological orientation factors of personal development of future psychologists. Synopsis of thesis for the scientific degree of Candidate of Psychological Sciences: 19.00.07. Odesa, 2009. (in Ukrainian)

[4] Kuznetsov N. Human Being: Needs and Values. Ural University Publishing, Sverdlovsk, 1992. (in Russian)

[5] Schnittker J. Gender and Reactions to Psychological Problems: An Examination of Social Tolerance and Perceived Dangerousness. Journal of Health and Social Behavior, 41 (2) (Jun., 2000), 224-240. doi: $10.2307 / 2676307$

[6] Shulha R. Art and Axiological Orientations of Personality. Naukova dumka, Kyiv, 1989. (in Russian)

[7] Shustova L.P. The problem of tolerance formation in senior schoolchildren based on gender approach in education. Fundamental research, 5 (2008), 142-144. (in Russian)

[8] Saharso S. Culture, Tolerance and Gender. European Journal of Women's Studies, 10 (1) (Feb., 2003), 7-27. doi: 10.1177/1350506803010001786

Address: Liubomyra Piletska, Vitaliia Dobrovolska, Vasyl Stefanyk Precarpathian National University, 57, Shevchenko Str., Ivano-Frankivsk, 76018, Ukraine.

E-mail: piletskalybomyra@gmail.com; vitalina802@gmail.com

Received: 24.12.2018; revised: 27.03.2019.

Пілецька Дюбомира, Добровольська Віталія. Аксіологічна орієнтація як фактор формування гендерної толерантності у студентському віці. Журнал Прикарпатського університету імені Василя Стефаника, 6 (1) (2019), 121-125.

У статті здійснено теоретичний аналіз поняття “гендерна толерантність", визначено зовнішні та внутрішні чинники іï формування. Виокремлено рівні досліджуваного феномена: високий, середній і низький. Обгрунтовано основні принципи та структуру гендерної толерантності, що включає чотири компоненти (когнітивний, емоційний, поведінковий, ціннісний, які згруповано у три блоки: когнітивний, мотиваційний, діяльнісний, а також виокремлено індикатори гендерної толерантності. Виокремлено характеристики, які поєднуе в собі толерантна особистість. Відзначено, що ціннісні орієнтації є внутрішнім чинником формування гендерної толерантності, які вкдючають в себе настанови, переконання, потреби, цілі, мотиви, ідеали, установки й цінності. Наголошено на важливості вивчення психологічної статі особистості, цінностей, установок і переконань, міру прийняття гендерних стереотипів у межах досліджуваної проблеми, що дозволить підвищити рівень iі гендерної культури.

Кдючові слова: гендерна толерантність, ціннісні орієнтації, настанови, переконання, потреби, цілі, мотиви, ідеали, установки, цінності, психологічна стать, гендерні стереотипи. 